\title{
Study of Program Innovation Based on the Quality of TV Directors
}

\author{
Peng Xiao \\ Shanghai Publishing and Printing College, Shanghai, China \\ Email:xp1212@163.com
}

How to cite this paper: Xiao, P. (2018). Study of Program Innovation Based on the Quality of TV Directors. Advances in Journalism and Communication, 6, 90-94. https://doi.org/10.4236/ajc.2018.63008

Received: July 16, 2018

Accepted: September 25, 2018

Published: September 28, 2018

Copyright $\odot 2018$ by authors and Scientific Research Publishing Inc. This work is licensed under the Creative Commons Attribution International License (CC BY 4.0).

http://creativecommons.org/licenses/by/4.0/

\begin{abstract}
The quality of TV directors is closely related to program innovation. The effect of program innovation is affected by the quality of TV directors, that is to say, the quality of TV directors has an impact on the sustainable development of TV programs. The work of TV directors is not limited to the selection of materials, and production. TV directors should be highly sensitive to news and have strong innovation capability, which can ensure the constant success of TV programs. This paper objectively analyzes the quality of TV directors and explores TV program innovation.
\end{abstract}

\section{Keywords}

TV Directors, Quality, Program, Innovation

\section{Background}

In an era of internet, the advantages of TV media are increasingly reduced. Many TV programs are closed due to the pressure from internet programs. According to relevant statistics, about a third of Internet users choose to read electronic news online and lose interest in their television media. The impact of the Internet has reduced TV ratings by thirty-five percent. Internet media has a great impact on TV media and leaves it in a difficult situation. In light of this situation, TV directors, the coordinator and planner of TV programs, should keep pace with the times and attach importance to the improvement of comprehensive quality, especially the sensitivity to news and innovation capability. TV directors should analyze the subjective and objective factors in all respects, optimize and innovate TV programs from multiple perspectives and at varied levels in accordance with the characteristics of TV media and internet media. Inject fresh blood into TV programs and make them develop according to the objective law. In February 2016, the BBC decided to shut down its television chan- 
nels on the BBC Three channel, which mainly caters to young people, and to retain only the Internet channels. During the 2016 Rio Olympics, NBC ratings in the U.S. dropped $20 \%$ from four years ago, and the process of canceling traditional TV subscriptions to move to digital streaming is accelerating. TV directors should help TV programs out of the difficult situation and achieve the long-term development.

\section{Quality Requirements for TV Directors}

\subsection{Sound Professional Qualities and Abundant Life Experience}

In the process of planning and production, TV directors should adhere to the principle of "pragmatism and entertainment" in health and entertainment programs. Thus sound professional qualities and abundant life experience are required for TV directors. The work of TV directors is complicated. For example, select a proper subject based on the everyday life, edit and produce the content after the planning, interview and shooting, and make a series of innovations concerning the works of the program. In terms of the content of a program, TV directors should have multiple capabilities, such as the selection of a subject, planning, the arrangement of interview and shooting. TV directors should comprehensively understand the characteristics of all the parts. Develop relevant skills to meet the actual requirements of the society. Create more charming programs closely related to the life of ordinary people. The program should reflect the real life so as to attract the public and meet the personalized requirements of them.

\subsection{High Professional Sensitivity and Innovation Capabilities of Selecting Materials}

In China, building socialist culture and ethics and advancing the cultural industry are mentioned many times in relevant national policies. Under the guidance of the State Administration of Radio, Film and Television, TV directors should put the market first, attach importance to the further study, and improve the comprehensive qualities, especially the professional sensitivity and innovation capabilities (Zhang, 2016). TV directors should quickly discover the new materials nobody finds, and put forward more unique ideas in accordance with the objective law of the social development. In the context of the daily change of media, in order to improve the effect of a program, the program should objectively convey the message to the audience and bring the enjoyment of beauty to them. TV directors should innovate the program in real terms.

\section{Program Innovation Based on the Quality of TV Directors}

\subsection{The Reflection of the Quality of TV Directors in Program Innovation}

\subsubsection{Shooting and Interview}

In terms of TV programs, video and sound materials are important carriers of 
expression and should be obtained by shooting and interview. TV directors should analyze the concrete location and figures in the shooting and interview and design them in a scientific and proper way, and make the relevant arrangements. Implement the plan and make an emergency plan including all the emergencies in shooting and interview. Thus the qualities of TV directors are closely related to the smoothness of the shooting and interview, and are the key to improving the overall quality of the program and program innovation.

\subsubsection{Program Production}

TV directors should carefully examine the political content and transcript of a program, and confirm the broadcasting order and form of the materials. Accurately understand the concrete combining form and transition method. Integrate dispersed information and systematize it to make the public better understand the program. Take You Are the One as an example, in the process of shooting and interview, TV directors should know the concrete content in all respects, for example, the sound and pictures should be optimized and employ the light prediction method to provide important reasons for the shooting of relevant programs. Make colorful VCR to attract the audience and make the audience comprehensively and objectively know the guest in a short period of time. Thus the program can leave a deep impression on the audience and improve its image among its target audience, which can ensure the effect of the program. In producing this program, TV directors should select the female guest of varied characteristics according to the program characteristics and intentionally arrange and design the type of male guest and their behavior difference. Thus the program seems natural and innovative. All of these require the TV directors to have relevant qualities.

\subsection{Improve the Quality of the TV Directors and Innovate the TV Program}

\subsubsection{Strengthen the Appreciation Ability of Art and Foster Their Devotion to Work}

In terms of program innovation, the program should have its own features, such as the content and broadcasting form. The broadcasting time is fixed and not too long. In order to innovate a program, TV directors should keep healthy and can overwork, and know the work in all respects. Improve the appreciation ability of art in all respects and at multiple levels. Discover the content the audience may be interested in and optimize and innovate the program. Despite the fact that target audience receives relevant information passively, they can enjoy the beauty feel pleased, and reduce the pressure. This can make the program more attractive and improve the TV ratings.

\subsubsection{Improve the Capability of the Selection of Materials and Innovation}

To some degree, in the process of program innovation, the requirements about the national policies should be met. Optimize, innovate and effectively develop 
the program to make it more original. This requires the high capabilities of selection of materials and innovation. Fully realize the importance of training TV directors (Li, 2014). As the society develops and the living standard increasingly improves, more attention is paid to health. Many health programs emerge. There is a craze for "health". In order to stand out from many programs, a health program should innovate itself. TV directors should select more representative and targeted materials and conducts an in-depth study of the materials, innovate the program from multiple perspectives and make it unique. Take "health vision" as an example, in the new era, optimize and innovate the traditional form of live broadcasting of medical specialists. Take a field trip and conduct a series of discussions and analysis to optimize and innovate the program. Thus the program can be more flexible and diversified and attract more audience. It is easy for the audience to remember the name of this program and TV ratings will be improved. In the progress of fostering the innovation qualities of TV directors, set up a new scientific mechanism of innovation and strengthen their awareness of innovation. Attach importance to the innovation of knowledge and thinking, constantly improve their knowledge system. Lay a solid foundation for theory learning. Employ the innovative thinking to present the program in a unique way. Thus the quality of this program can be improved. In this process, TV directors should keep pace with times and break the traditional thinking mode and put the market first. Innovate the content of the program, add its value of appreciation and prolong the life of a program. Especially the art program has a sound TV rating. Due to the special rules of TV industry, TV directors should focus on the demand and effectively solve the existing problems and present their own artistic style and produce the TV programs in a proper way.

\section{Conclusion}

To conclude, TV directors play an irreplaceable role in program innovation. Improve the comprehensive qualities from multiple perspectives and at varied levels. TV directors should have high professional sensitivity and innovation capabilities, and conduct an in-depth study of important materials and optimize the program form to make it more original and unique. Meet the diversified demand of the audience and improve the satisfying degree of the program. Further enhance the market influence of TV media. In the era of internet, the television media will be brought into the network age, we should continue to grow and expand effectively to cope with the rapidly changing social market. TV directors should effectively adapt to the changing market environment and pursue the sustainable development for wider development prospect.

\section{Conflicts of Interest}

The authors declare no conflicts of interest regarding the publication of this paper. 


\section{References}

Li, A. (2014). Analysis of Program Innovation Based on the Quality of TV Directors. Journalism \& Communication, No. 12, 23.

Zhang, M. D. (2016). The Relationship between the Quality of TV Directors and Program Innovation. New Media Research, No. 2, 99-100. 